\title{
STUDY REGARDING THE DEVELOPMENT OF JUMPING ABILITY IN BASKETBALL GAME
}

\author{
Marcel POMOHACI \\ "Lucian Blaga” University, Sibiu, Romania \\ marcelpomohaci@yahoo.com \\ Ioan Sabin SOPA \\ "Lucian Blaga" University, Sibiu, Romania \\ sopa_sabin@yahoo.com
}

\begin{abstract}
Modern basketball game is becoming more and more physical, and coaches have reoriented their view on building strong athletes with speed, strength, and accuracy. Jumping ability is used in many moves in basketball, from rebounding, defending, jump shoot, blocking till interception and offensive game. The vertical jump is the primary and essential skill in the jumping ability of a basketball player. Our research focused on the result of a questionnaire with 20 respondents that were coaches at different levels regarding the importance of vertical jump in the basketball game. The conclusions highlighted that vertical jump is considered necessary also for small players (point guard, shooting guard) and tall players (short forward, power forward, center), with emphasis on small players who have to compensate for their height with an excellent vertical jump; also the contribution of coordination and endurance, nutrition and appropriate rest periods can contribute decisively to the jumping ability. Also, between the methods of developing vertical jump was underlined the plyometric and circuit training.
\end{abstract}

KEYWORDS: vertical jump, basketball training, motor development

\section{Introduction}

The quality of "vertical jump" is a combination of two essential motor qualities: strength and speed. The combination of force and speed appears under numerous names in the literature: explosive force, motor force force-speed, force in speed regime, all expressing a single idea, the manifestation of motor quality force in combination with speed.

In the specialized literature, it is found under different names: explosive force, vertical jump, elastic force, speed force, and fast force. Also, the product of the muscular force (F) multiplied by the speed of movement $(\mathrm{S})$ is equivalent to the power $(\mathrm{P})$.

$$
\mathrm{P}=\mathrm{F} * \mathrm{~S}
$$

The capacity of the neuromuscular system to generate the most significant force in the shortest amount of time is referred to as strength (Bompa, 2002).

We distinguish two other forms in strength-speed training: starting force and explosive force (Weineck, 2003).

As several authors have already shown over time, speed (acyclic and cyclic) is closely related to maximum force, force-velocity, and pure velocity, depending mainly on existing forces (Weineck, 2003). According to other authors (Balint, 2008), the vertical jump is a complex ability, resulting from the combination of force and speed, coordinated to achieve movement with maximum efficiency. 
The vertical jump depends mainly on the following factors:

- the muscle fibers that contract at the same time (intramuscular coordination);

- speed of contraction of active muscle fibers (faster mobilization of phosphates from both fibers and red ones);

- ability to contract muscle fibers (fiber thickness, cross-section). So, the maximum force largely determines the explosive force, but also another type of force, called by some authors "start-up", which, in turn, influences the vertical jump.

Regarding the definition of vertical jump ability, some disagreement among experts. Some of them consider this ability as speed in the force regime. Others were assuming that it is, in fact, explosive force (force in speed regime) (Bompa, 2002).

According to V. Tudor (1999), the difference between the two forms is the predominance of a quality. If at the vertical jump, the predominant quality is speed (above $50 \%$ speed and below $50 \%$ force), an explosive force, and the predominant quality is force (above $50 \%$ force and less than $50 \%$ speed). Research conducted has shown the existence of close links between maximum force and speed of movement. The increase in force as a parameter of the ability to jump depends on three factors:

- Muscle coordination;

- The speed of contraction of the muscle fibers involved in the effort.

The contraction force of the involved muscle fibers depends on the cross-section of the muscle (Cârstea, 2000).

It is known that the main ingredients of the jumping ability are the explosive force and the starting force (Șerbănoiu, 2004). The explosive force translates into the ability to obtain a sudden increase in force per unit time and depends on the speed of contraction of the basic units, the number, and force of contraction of the fibers used in the effort (Dragnea \& Teodorescu, 2002).
Jumping ability is a complex movement that requires coordination of several muscles in the torso, arms, and legs. This type of movement is the crucial component frequently used during basket throwing or recovering the ball in basketball and could significantly contribute to victory. From a clinical perspective, the ability to perform a vertical jump is a reliable indicator of lower limb strength that has been validated in a wide range of populations (Rittweger, 2004; Farias, 2013).

In essence, jumping the individual can engage in effort, in a short time, many neuromuscular units. Globally, the problem is to train the performance player to successfully cope with the growing demands of basketball in major national and international competitions (Ghițescu et al., 2013).

Explosive force is the ability of a muscle to perform a specific muscular effort in the minimum time; it is a combination of motor qualities. The explosive force is specific to basketball. The ability to jump, dynamic jumps to recover the ball, sudden jumps, dynamic actions to score baskets, sudden jumps to throw the ball, and, in general, the whole dynamic action involved in the game are strictly related to the nature of this force and speed of the game. The ability to jump is closely linked to explosive force (Tudor, 1999).

In general, basketball players' athletic talent is a multidimensional capability that includes morphological traits, physical fitness, technological and tactical capabilities, and analytical abilities (Ostojic et al., 2006; Köklü et al., 2011). This ability is positively associated with future career achievements and highly competitive success (Berri et al., 2011; Teramoto et al., 2017). Among all the factors related to athletic ability, morphological characteristics are placed in the primary place during the evaluation and selection of players (Vaquera et al., 2015). 
In particular, height and weight would be essential when establishing players' field positions (Dežman et al., 2001).

Together with upper limb length and standing height, these factors could influence players' match performance in the game situation and predict whether these athletes will reach the top level in basketball (Apostolidis \& Emmanouil, 2015; Garcia-Gil et al., 2018).

Although due to the physically demanding characteristics of basketball, players are required to perform various high-intensity actions and quick reactions in a short period during the game, such as sprinting, dribbling, shuffling, jumping, and quick change of direction (Ben Abdelkrim et al., 2010; Alemdaroğlu, 2012). Therefore, physical fitness is usually considered an essential factor that determines the development of other athletic skills to a large extent. Because all these functional, technical, and tactical activities are made possible due to the muscular strength of elite upper and lower limb players, speed, agility, and coordination at the elite level (Hoare, 2001; Ostojic et al., 2006; Fort-Vanmeerhaeghe et al., 2016).

Indeed, these fitness skills are considered more important for high-level basketball players because the level of aerobic fitness is not a solid discriminating feature between professional and semi-professional players (Köklü et al., 2011; Ferioli et al. al., 2018), and success in basketball depends more on the anaerobic power of players (Hoffman and Maresh, 2000).

Previous research has devised a variety of physical fitness measures to evaluate basketball players' individual muscle performance, muscle performances of basketball players (Erculj et al., 2010; Alemdaroğlu, 2012; Conte et al., 2018). For example, the vertical jump test found that the vertical jump heights were similar between different playing positions, and the elite basketball player would have vertical jump values greater than $60 \mathrm{~cm}$ and maximum vertical values greater than $80 \mathrm{~cm}$. (Ostojic et al., 2006; Mehran et al., 2016). Furthermore, professional extremes and foundations outperformed centers in sprint and endurance results (Köklü et al., 2011).

The National Basketball Association (NBA) is the most elite men's basketball league in the world, putting together the best basketball players from all over the world (Sampaio et al., 2018).

Since 2000, in Chicago, he has hosted an annual combination project that includes a series of standardized measurements and performance testing programs to help NBA team directors evaluate and identify potential talent. In the combined test, the players' anthropometric, athletic and technical skills will be examined, and the information obtained during this process will be essential for decision-makers to choose later those that meet their needs. However, research on the NBA project has been relatively rare. Mehran et al. (2016) found a similar performance of the combined test between players who had previously suffered cruciate ligament injuries and those without knee injuries.

The study of Teramoto et al. (2018) assumed that the length and upper body strength demonstrated during the draft was more akin to future field performance. Little is known about the difference between test scores between registered and unselected players. In addition, more evidence is needed to confirm which combined test factors could effectively predict the project's success if gamespecific positions were accounted for.

\section{Objectives of the Research}

The research objectives were mainly to inquire a group of experienced basketball coaches about the importance of vertical jump in a basketball game at every level or position. following:

The research stages were the

- finding the prominent opinions of the specialists in the domain of basketball, 
physical preparation, and coaching, regarding the problem of the importance of vertical jump in a basketball game;

- building the questionnaire and finding the best way to discover the importance of vertical jump at the basketball game;

- enquiring 20 basketball coaches about the importance of vertical jump on every position of the game;

- interpreting the data obtained at the questionnaire; research.

- discussions and conclusions of the

\section{Research Method}

In our research, we also used the survey method in the form of a questionnaire through which we tried to find out from experienced coaches the importance of relaxation in the game of basketball and the most effective methods for developing this combined motor quality.

Twenty basketball coaches from different age levels were interviewed, with at least five years of coaching experience.

The questionnaire had ten items with five variants or a scale with five fixed answer variants (disagreement, partial disagreement, partial agreement, agreement, and strong agreement).

\section{Research Protocol}

\subsection{Research Place and Subjects}

The place of study was the gym of the "Lucian Blaga" University of Sibiu. The study period was between September 1, 2019 - December 31, 2019. It was used as a questionnaire for enquiring about the importance of vertical jump in a basketball game. The research subjects were 20 basketball coaches with different ages and levels of classification, having at least five years of experience.

\subsection{The Hypothesis of the Research}

The use of survey methods and other measurement and evaluation techniques specific to Physical Education and Sports can provide in-depth knowledge and a complex picture of the studied phenomena.

\section{Results}

In the analysis of the questionnaire addressed to the coaches regarding the importance of detention and the factors that limit it, we discovered the following:

At the first item: "Jumping is a decisive skill in the game of basketball", the results at the first item of the questionnaire were as follows.

The coaches surveyed mostly answered that they agree (40\% of the total number 8 out of 20) with the fact that relaxation is a decisive motor quality in the basketball game, only $5 \%$ agreed (1 coach out of 20), $25 \%$ only partially agreed (5 coaches out of 20), $25 \%$ of the coaches partially disagreed (5 coaches out of 20 ), and $5 \%$ of the total number disagreed with this statement (1 coach out of 20).

At the second item, "Tall athletes (power forward and center position) need the development of detention to be effective in the game of basketball", the coaches answered as follows: 7 out of 20 coaches (35\% of the total) agreed, 6 out of 20 (30\% of the total) agreed, 4 out of 20 (representing 20\%) agreed partially agreed, $15 \%$ ( 3 out of 20 coaches) disagreed with the statement, and none of the coaches disagreed.

At the third item: "Small and medium-sized athletes need more development in order to be effective in the game of basketball', coaches responded as follows: 9 out of 20 coaches (45\% of the total) agreed, 6 out of 20 (30\% of the total) agreed, 2 out of 20 (representing $10 \%$ of the total) agreed partially agree, 2 (representing $10 \%$ of the total) disagreed with the statement and one coach disagreed. 
At the forth item, "Food contributes to the development of jumping", the coaches responded as follows: 9 out of 20 coaches (45\% of the total) agreed in total, 6 out of $20(30 \%$ of the total) agreed, 2 out of 20 (representing $10 \%$ of total) partially agreed, 2 (representing $10 \%$ of the total) disagreed with the statement and one coach disagreed.

At the fifth item, "Athlete's rest level can cause poor performance in the development of jumping", coaches responded as follows: 9 out of 20 coaches (45\% of the total) agreed, 6 out of 20 (30\% of the total) agreed, 3 out of 20 (representing $15 \%$ of the total) agreed partially agreed, one coach (representing $5 \%$ of the total) disagreed with the statement, and one coach out of 20 (representing $5 \%$ of the total) strongly disagreed.

At the sixth item, "Plyometric training is the best way to develop jumping", the coaches responded as follows: 4 out of 20 coaches $(20 \%$ of the total) agreed, 6 out of 20 (30\% of the total) agreed, 5 out of 20 (representing $15 \%$ total) partially agreed, two coaches (representing $5 \%$ of the total) disagreed with the statement, and three coaches out of 20 (representing 15\% of the total) disagreed.

At the seventh item: "The efficiency of circuit training can have a positive impact on jumping skill', the coaches responded as follows: 4 out of 20 coaches (20\% of the total) agreed, 8 out of 20 (40\% of the total) agreed, 4 out of 20 (representing $20 \%$ of totally) agreed, two coaches (representing 10\% of the total) disagreed with the statement, and two coaches out of 20 (representing $10 \%$ of the total) totally disagreed.

At the eighth item, "The development of coordination and resistance contributes to the development of jumping", the coaches responded as follows: 4 out of 20 coaches (20\% of the total) agreed, 4 out of 20 (20\% of the total) agreed, 2 out of 20 (representing $10 \%$ of total) agreed, five coaches (representing $25 \%$ of the total) disagreed with the statement, and five coaches out of 20 (representing $25 \%$ of the total) disagreed.

At the ninth item: "The muscular implications of the lower limbs contribute decisively to the manifestation of relaxation", the coaches responded as follows: 15 out of 20 coaches $(75 \%$ of the total) agreed, 2 out of 20 (10\% of the total) agreed, 2 out of 20 (representing $10 \%$ of totally) partially agreed, one coach (representing $5 \%$ of the total) disagreed with the statement, and none of the 20 coaches disagreed.

At item number ten: "In the composition of jumping, the manifestation of force is more important than that of speed", the coaches responded as follows: none of the 20 coaches agreed, 2 of 20 (10\% of the total) agreed, 3 of 20 (representing $15 \%$ of the total) agreed partially agree, seven coaches out of 20 (representing $35 \%$ of the total) disagreed with the statement, 8 of the coaches (representing $40 \%$ of the total) disagreed.

\section{Discussions}

The vertical jump is also a component of physical ability (Logan et al., 2017) and peak leg power (Taylor et al., 2010). Basketball players of all ages must be able to win air challenges, and jumping skill is needed to increase results (Meylan et al., 2012). Basketball also has a high jump average and is seen as a high-risk sport with injuries such as knee or ankle sprains (Kerr et al., 2017; Drakos et al., 2010; Policastro et al., 2020).

A low-fat percentage can help athletes increase their success in sports that entail many jumps and sprints, such as basketball. According to Lohman et al. (Lohman et al., 1999), the overweight ratio of young male adults is below the population mean when found in a range of 8 to 22 percent. A basketball player with a percent body fat 
(BF) higher than the population mean is expected to struggle when playing against teams with a percent body fat (BF) greater than 22 percent. Furthermore, the high degree of physical interaction that happens during the game is well-known. As a result, strength and muscle power are essential for high-level basketball success. An effective kinanthropometry profile seems to maximize the potential to generate force and strength (Ribeiro et al., 2015). According to Iqbal (2015), a jump shoot is a very effective shot that is difficult for opponents to block. In line with that, Wijaya (2017) argues that the jump shot is an effective shooting technique because shooting in a jumping position with the initial squatting position will be very difficult to be blocked by the opponent (Bangun et al., 2021). Based on these two opinions, it can be concluded that jumping ability in basketball is an important skill.

Several papers investigated the planning aspect of plyometric in training (Szabo et al., 2020, Sopa \& Szabo, 2015), the planning of strength development (Tulbure et al., 2020), and the role of physical training in volleyball (Szabo, 2014; Szabo, 2015a; Szabo, 2015b; Szabo \& Sopa, 2015; Szabo et al., 2019). We found one article that discussed the preparation aspect of stress control in students (Popa et al., 2020), as well as two that addressed the sports psychopedagogical aspect (Ardelean et al., 2020).

Jump height $(\mathrm{JH})$ is the most reported and arguably the most crucial vertical jump performance measure (Claudino et al., 2017; Stojanovic et al., 2017). The majority of studies measuring and estimating $\mathrm{JH}$ have employed FPs, contact mats, or vertical jump apparatuses (e.g., Vertec) as the primary measurement system(s) (Buckthorpe et al., 2012; Chiu \& Daehlin, 2019; Garcia-Lopez et al., 2013; Montoye \& Mitrzyk, 2018; Nuzzo et al., 2011). However, significant differences in $\mathrm{JH}$ have been reported between these measurement systems; therefore, caution is advised when selecting the most appropriate system to measure and method to estimate $\mathrm{JH}$ (Buckthorpe et al., 2012). JH estimation from FP is commonly based on take-off velocity, which is commonly calculated from the vertical ground-reaction force-time data using i) the impulse-momentum method or ii) the double integration of acceleration-time data (Chiu \& Daehlin, 2019; Moir, 2008).

Vertical jumps are commonly used to evaluate the function of lower-body muscles due to the high reliability, validity, and sensitivity of their outcomes (Mandic et al., 2015; Markovic et al., 2004).

\section{Conclusions}

As modern basketball game is becoming more and more physical, and coaches have reorientated their view on building strong athletes with speed, strength, and accuracy. As international scientific research underlines, the jumping ability is used in many moves in basketball, from rebounding, defending, jump shot, blocking till interception and offensive game. The vertical jump is the primary and essential skill in the jumping ability of a basketball player. The conclusions of our investigation showed that coaches from Romania consider that vertical jump represents an essential skill in the basketball game. Our investigation discovered that vertical jump is considered essential for small players (point guard, shooting guard) and tall players (short forward, power forward, center), emphasizing small players who have to compensate for their height with an excellent vertical jump.

Also, other conclusions of our research highlighted that nutrition and rest periods are considered very important in vertical jumping performance; athletes with good nutrition and adequate periods of rest register better performances in jumping. 
Plyometric and circuit training are considered by the sample of coaches who answer our inquiries, the most efficient training methods for developing vertical jump in the basketball game.
The sample of coaches also considers the development of coordination and endurance investigated very important in the development of the jumping ability.

\section{REFERENCES}

Alemdaroglu, U. (2012). The Relationship between Muscle Strength, Anaerobic Performance, Agility, Sprint Ability and Vertical Jump Performance in Professional Basketball Players. Journal of Human Kinetics, Vol. 31, Issue 1, 149-158. DOI: 10.2478/v10078-012-0016-6.

Apostolidis, N., \& Zacharakis, E. (2015). The influence of the anthropometric characteristics and handgrip strength on the technical skills of young basketball players. Journal of Physical Education and Sport, Vol. 15, Issue 2, 330-337. DOI:10.7752/jpes.2015.02050.

Ardelean M., Neagu N., \& Szabo, D.A. (2020). Pedagogical considerations regarding the structure of high school lower cycle syllabuses, for the "Theoretical Sports Training" school subject (Note I). Health, Sports \& Rehabilitation Medicine, Vol. 21, Issue 4, 256-259. https://doi.org/10.26659/pm3.2020.21.4.256

Ardelean M., Neagu N., \& Szabo, D.A., (2021). Pedagogical considerations regarding the structure of high school upper cycle syllabuses, for the "Theoretical Sports Training" school subject (Note II). Health, Sports \& Rehabilitation Medicine, Vol. 22, Issue 1, 36-39. https://doi.org/10.26659/pm3.2021.22.1.36

Balint, G. (2008). Baze teoretice de acţionare pentru pregătirea fizică specifică a jucătorilor de fotbal. Pim.

Bangun, S.Y., Nugraha, T., \& Handika, R. (2021). Dribble training model development jump shoot basketball sports branch on students. Kinestetik: Jurnal Ilmiah Pendidikan Jasmani, Vol. 5, Issue 1, 163-170. DOI:10.33369/jk.v5i1.13630.

Ben Abdelkrim, N., Castagna, C., Jabri, I., Battikh, T., El Fazaa, \& El Ati, J. (2010). Activity profile and physiological requirements of junior elite basketball players in relation to aerobic-anaerobic fitness. The Journal of Strength and Conditioning Research, Vol. 24, Issue 9, 2330-42. DOI: 10.1519/JSC.0b013e3181e381c1.

Berri, D., Brook, S.L., \& Fenn, A.J. (2011). From college to the pros: Predicting the NBA amateur player draft. Journal of Productivity Analysis, Vol. 35, Issue 1, 25-35. DOI: $10.1007 / \mathrm{s} 11123-010-0187-\mathrm{x}$

Bompa, T.O. (2002). Periodizarea: teoria şi metodologia antrenamentului. Bucharest: ExPonto, C.N.F.P.A., p. 316.

Buckthorpe, M., Morris, J., \& Folland, J.P. (2012). Validity of vertical jump measurement devices. Journal of Sports Science, Vol. 30, Issue 1, 63-69. https://doi.org/10.1080/02640414. 2011.624539

Cârstea, G. (2000). Physical education and sport theory and methodology. Bucharest: ANDA Publishing House.

Chiu, L.Z., \& Daehlin, T.E. (2019). Comparing numerical methods to estimate vertical jump height using a force platform. Measurement in Physical Education and Exercise Science, Vol. 24, Issue 1, 25-32. https://doi.org/10.1080/1091367X. 2019.1650044. 
Claudino, J.G., Cronin, J., Mezencio, B., McMaster, D.T., McGuigan, M., Tricoli, V., \& Serrao, J.C. (2017). The countermovement jump to monitor neuromuscular status: A meta-analysis. Journal of Science and Medicine in Sport, Vol. 20, Issue 4, 397-402. https://doi.org/10.1016/j.jsams.2016.08.011

Conte, E., Ornaghi, V., Grazzani, I., Pepe, A., \& Cavioni, V. (2019). Emotion Knowledge, Theory of Mind, and Language in Young Children: Testing a Comprehensive Conceptual Model. Frontiers in Psychology, Vol. 19, https://doi.org/ 10.3389/fpsyg.2019.02144

Dezman, B., Trnincic, S., \& Dizdar, D. (2001). Models of expert system and decisionmaking systems for efficient assessment of potential and actual quality of basketball players. Kinesiology, Vol. 33.

Dragnea, A., \& Teodorescu, S. (2002). Sport's theory. Bucharest: Fest Publishing House.

Drakos, M.C., Domb, B., Starkey, C., Callahan, L., \& Allen, A.A. (2010). Injury in the National Basketball Association: A 17-year overview. Sports Health, Vol. 2, Issue 4, 284-290.

Erculj, F., Blas, M., \& Bracic, M. (2010). Physical Demands on Young Elite European Female Basketball Players with Special Reference to Speed, Agility, Explosive Strength, and Take-off Power. The Journal of Strength and Conditioning Research, Vol. 24, Issue 11, 2970-2978. DOI: 10.1519/JSC.0b013e3181e38107.

Farias, D.L., Teixeira, T.G., Madrid, B., Pinho, D., Boullosada, D.A., \& Prestes, J. (2013). Reliability of vertical jump performance evaluated with contact mat in elderly women. The Authors Clinical Physiology and Functional Imaging, Vol. 33, 288-92.

Ferioli, D., Rampinini, Bosio, A., La Torre, A., Azzolini, M., Coutts, A. J. (2018). The physical profile of adult male basketball players: Differences between competitive levels and playing positions. Journal of Sports Sciences, Vol. 36, Issue 6. DOI: $10.1080 / 02640414.2018 .1469241$

Fort-Vanmeerhaeghe, A., Montalvo, A.M., Latinjak, A.T., \& Unnithan, V. (2016). Physical Characteristics of Elite Adolescent Female Basketball Players and their Relationship to Match Performance. Journal of Human Kinetics, Vol. 53, Issue 53, 167. DOI:10.1515/hukin-2016-0020

Garcia-Gil, M., Torres-Unda, J., Esain, I., Dunabeitia, I., Gil, S.M., Gil, J., \& Irazusta, J. (2017). Anthropometric Parameters, Age, and Agility as Performance Predictors in Elite Female Basketball Players. The Journal of Strength and Conditioning Research, Vol. 32, Issue 6, 1. DOI: 10.1519/JSC.0000000000002043.

Garcia-Lopez, J., Morante, J.C., Ogueta-Alday, A., \& Rodriguez-Marroyo, J.A. (2013). The type of mat (Contact vs. Photocell) affects vertical jump height estimated from flight time. Journal of Strength and Conditioning Research, Vol. 27, Issue 4, 1162-1167. https://doi.org/ 10.1519/JSC.0b013e31826520d7.

Ghițescu, I.G., Tudor, V., \& Moanţă, A.D. (2013). Study on the development of vertical jumping force in U18 junior basketball players. ICSPEK 2013, Elsevier - Procedia Social and Behavioral Science, Vol. 117, 55-59.

Hoare, D.G. (2001). Predicting success in junior elite basketball players The contribution of anthropometic and physiological attributes. Journal of Science and Medicine in Sport, Vol. 3, Issue 4, 391-405. DOI: 10.1016/S1440-2440(00)80006-7.

Hoffman, J.R. (2008). Physiology of Basketball. Handbook of Sports Medicine and Science: Basketball. DOI: 10.1002/9780470693896.ch2 
Iqbal, K., Abdurrahman, A., \& Ifwandi, I. (2015). Kontribusi Daya Ledak Otot Tungkai dan Keseimbangan terhadap Ketrampilan Jump Shoot dalam Permainan Bola Basket pada Atlet Unit Kegiatan Mahasiswa Universitas Syiah Kuala. Journal Ilmiah Mahasiswa Pendidikan Jasmani, Kesehatan dan Rekreasi, Vol. 1, Issue 2.

Kerr, Z.Y., Lynall, R.C., Roos, K.G., Dalton, S.L., Djoko, A., \& Dompier, T.P. (2017). Descriptive epidemiology of non-time-loss injuries in collegiate and high school studentathletes. Journal of Athletic Training, Vol. 52, Issue 5, 446-456.

Koklu, Y, Asci, A, Kocak, F.U., Alemdaroglu, U., \& Dundar, U. (2011). Comparison of the physiological responses to different small-sided games in elite young soccer players. Journal of Strength and Conditioning Research, Vol. 25, Issue 6, 1522-1528.

Logan, S.W., Barnett, L.M., Goodway, J.D., \& Stodden, D.F. (2017). Comparison of performance on process and product-oriented assessments of fundamental motor skills across childhood. Journal of Sports Sciences, Vol. 35, Issue 7, 634-641.

Lohman, T.G., Roche, A.F., \& Marorell, R. (1999). Anthropometric Standardization Reference Manual. Human Kinetics Books, Champaign: IL.

Mandic, R., Jakovljevic, S., \& Jaric, S. (2015). Effects of countermovement depth on kinematic and kinetic patterns of maximum vertical jumps. Journal of Electromyography and Kinesiology, Vol. 25, 265-272. DOI:10.1016/j.jelekin.2014.11.001

Markovic, G., Dizdar, D., Jukic, I., \& Cardinale, M. (2004). Reliability and factorial validity of squat and countermovement jump tests. Journal of Strength and Conditioning Research, Vol. 18, 551-555.

Mehran, N., Williams, P.N., Keller, R.A., Khalil, L.S., Lombardo, S.J., \& Kharrazi, F.D. (2016). Athletic Performance at the National Basketball Association Combine After Anterior Cruciate Ligament Reconstruction. Orthopaedic Journal of Sports Medicine, Vol. 25, Issue 4(5). DOI:10.1177/2325967116648083.

Meylan, C.M., Cronin, J.B., Oliver, J.L., Hughes, M.G., \& McMaster, D. (2012). The reliability of jump kinematics and kinetics in children of different maturity status. The Journal of Strength \& Conditioning Research, Vol. 26, Issue 4, 1015-1026.

Montoye, A.H.K., \& Mitrzyk, J. (2018). Validity of the blast athletic performance monitor for assessing vertical jump height in female volleyball players. Measurement in Physical Education and Exercise Science. https://doi.org/10. 1080/1091367X.2018.1539739

Nuzzo, J.L., Anning, J.H., \& Scharfenberg, J.M. (2011). The reliability of three devices used for measuring vertical jump height. Journal of Strength and Conditioning Research, Vol. 25, Issue 9, 2580-2590. https://doi.org/10.1519/JSC. 0b013e3181fee650

Ostojic, S.M., Mazic, S., \& Dikic, N. (2006). Profiling in basketball: Physical and physio-logical characteristics of elite players. Journal of Strength and Conditioning Research, Vol. 20, Issue 4, 740.

Policastro, F., Sardo, A., Yazbek, F., \& Accardo, A. (2020). Kinematic assessment of the vertical jump in young basketball players. Journal of Physical Education and Sport, Vol. 20, Issue 6, 3229-3233. DOI:10.7752/jpes.2020.s6438.

Popa, C.O., Schenk, A., Rus, A., Szasz, S., Suciu, N., Szabo, D.A., \& Cojocaru, C. (2020). The Role of Acceptance and Planning in Stress Management for Medical Students. Acta Marisiensis - Seria Medica, Vol. 66, Issue 3, 101-105.

Ribeiro, B.G., Mota, H.R., Sampaio-Jorge, F., Morales, A.P., \& Leite, T.C. (2015). Correlation between Body Composition and the Performance of Vertical Jumps in Basketball Players. Journal of Exercise Physiology, Vol. 18, Issue 5, 69-78. 
Rittweger, J., Schiessl, H., Felsenberg, D., \& Runge, M. (2004). Reproducibility of the jumping mechanography as attest of mechanical power output in physically competent adult and elderly subjects. Journal American Geriatrics Society, Vol. 52, 128-31.

Sampaio, J., Goncalves, B., Mateus, N., Liang, Z.S., \& Leite, N. (2018). Team Sports and the Modelling of Playing Processes and Tactical Behaviour: Basketball. Modelling and Simulation in Sport and Exercise. Routledge Publishing House.

Şerbănoiu, S. (2004). The physical education and sport methodology. Bucharest: University Book Publishing House.

Sopa, I.S., \& Szabo, D.A. (2015). Testing agility and balance in volleyball game. Discobolul Phys Educ Sport Kinetother Journal, Vol. 11.3, Issue 41, 167-174.

Stojanovic, E., Ristic, V., McMaster, D.T., \& Milanovic, Z. (2017). Effect of plyometric training on vertical jump performance in female athletes: A systematic review and metaanalysis. Sports Meicine, Vol. 47, Issue 5, 975-986.

Szabo, A., Szucs, A., Gaspar, Z., \& Sule, K. (2014). Anxiety and affect in successful and less successful elite female basketball players: In-situ sampling before six consecutive games. Lase Journal of Sports Science, Vol. 5, Issue 2, 75-92.

Szabo, D.A. (2015a). Modalities of Using the Information Provided by the Statistical Program Click and Scout for Improving the Outside Hitters Service Efficiency in Volleyball Game. The European Proceedings of Social \& Behavioral Sciences EpSBS, XI, 341-347. http://dx.doi.org/10.15405/epsbs.2016.06.47

Szabo, D.A. (2015b). Study on improving the service unforced errors in volleyball game by using a statistical software. Conference proceedings of eLearning and Software for Education (eLSE), Issue 3, 320-326.

Szabo, D.A., \& Magdaş, L. (2014). Increasing the defensive efficiency in volleyball using the statistical program "Click\&Scout". Conference proceedings of eLearning and Software for Education (eLSE), Issue 1, 223-228.

Szabo, D.A., Neagu, N., \& Sopa, I.S., (2020). Research regarding the development and evaluation of agility (balance, coordination and speed) in children aged 9-10 years. Health, Sports \& Rehabilitation Medicine, Vol. 21, Issue 1, 33-40. https://doi.org/ 10.26659/pm3.2020.21.1.33

Szabo, D.A., Neagu, N., Teodorescu, S., \& Sopa, I.S. (2019). Modalities of exploitation the information provided by the Click \& Scout statistical program in preparing volleyball attack players. International Journal of Applied Exercise Physiology, Vol. 8, Issue 2.1, 852-859.

Szabo, D.A., \& Sopa, I.S. (2015). Study on the Interpretation of the Results in a Volleyball Game by Using a Specific Program of Statistics. Procedia Social and Behavioral Sciences, Vol. 180C, 1357-1363, Elsevier Publication.

Taylor, M.J., Cohen, D., Voss, C., \& Sandercock, G.R. (2010). Vertical jumping and leg power normative data for English school children aged 10-15 years. Journal of Sports Sciences, Vol. 28, Issue 8, 867-872.

Teramoto, M., Cross, C.L., Cushman, D.M., Maak, T.G., Petron, D.J., \& Willick, S.E. (2017). Game injuries in relation to game schedules in the National Basketball Association. Journal of Science and Medicine in Sport. Vol. 20, Issue 3, 230-235.

DOI: 10.1016/j.jsams.2016.08.020.

Tudor, V. (1999). Conditional, coordinative and intermediate capacities - components of motor capacities. Bucharest: Rai Publishing House.

Tulbure, R.E., Neagu, N., \& Szabo, D.A., (2020). Comparative study on the development of the motor skill (strength) through the circuit method versus dynamic games in physical education classes. Health, Sports \& Rehabilitation Medicine, Vol. 21, Issue 4, 223-230. https://doi.org/10.26659/pm3.2020.21.4.223 
Vaquera, A., Santos, S., \& Garcia-Tormo, V. (2015). Anthropometric Characteristics of Spanish Professional Basketball Players. Journal of Human Kinetics, Vol. 46, 99-106.

Weineck, J. (2003). Manuel d'entraînement. $4^{\text {th }}$ Editions Vigot, Paris.

Wijaya, R.A. (2017). Pengaruh Latihan Jump Stop Shoot dan Triple Threat Position Terhadap Hasil Jump Shoot Putra Ekstrakurikuler Bola Basket SMA Negeri 2 Pringsewu Tahun 2016/2017. Bachelor's thesis, Universitas Lampung: Fakultas Keguruan dan Ilmu Pendidikan. 